\title{
Landslide Susceptible Zonation mapping of Madikeri Taluk, Kodagu district of Karnataka, India using Remote Sensing and Geographic Information System Techniques
}

\section{Dr. Ramesh L Dikpal ${ }^{1 *}$, Dr. G S Srinivasa Reddy ${ }^{2}$}

1. Junior Scientific Officer, Karnataka State Natural Disaster Monitoring Centre, Bangalore, Karnataka, India,

2. Senior Consultant, Karnataka State Disaster Management Authority, Bangalore, Karnataka, India,

\begin{abstract}
Landslides are one of the most damaging disastrous phenomena that frequently lead to serious problems in hilly areas. Various impacts of landslides have increased in past decades due to the rapid growth of urbanization in the developing world. Kodagu district, a part of Western Ghat Region is a sensitive topography with a series of ridges and susceptible to frequent landslide occurrences and experienced ever known earthslides and mudslides along with floods affecting 19 casualties in the year 2018, majority of the landslide are occurred in the Madikeri taluk. High intensity and continuous monsoon seasonal rainfall is the common triggering factor. Remote sensing data and multiple weighted overlay analysis using GIS is carried out for the different thematic layers of lithology, geomorphology, lulc, slope, aspect, drainage density, soil, and rainfall are assigned ranking and weightages to delineate landslide susceptible zones. Cumulative rainfall of each 500mm interval is assigned higher ranking and weightages is processed to know the susceptible behavior in the study area and the resulting each map directly correlates to the susceptible zones.
\end{abstract}

Keywords: Madikeri, Landslide, GIS, Weighted Overlay index, KSNDMC, cumulative rainfall

\section{Introduction:}

A simple landslide definition according to Working Party on World Landslide Inventory (WP WLI) [1990] and Cruden [1991] is "The movement of a mass of rock, earth or debris down a slope".

Based on the defined terms by Varnes [1984], landslide hazard zonation can be explained as; division of land in homogeneous areas or domains and the ranking of these areas according to their degrees of actual or potential probability of occurrence of damaging phenomena of landsliding within a period of time.

Landslide hazard/slope instability phenomena involve many geological and geomorphological factors such as lithological, tectonical, erosional, vegetation removal etc. Intense rainfall, rapid snow melting and earthquakes are among important triggering factors in landslide processes. Human factors are also effective in this phenomenon.

The surface cracks are observed (Maruthi $K V$., et al 2013) in monnageri and makkandur villages of madikeri and the developments are warning towards initiation of slides. Undoubtedly the most effective factor of landslide initiation in Madikeri is rainfall; hence the high landslide risk area is a subset of the regions that receive intense precipitation. Furthermore, anthropomorphic activities like slope modification, 
diversion of drainage network, temporary ponds creations are an additional influence on this triggering factor. Absence of retaining structures is also leading towards elevated quantity of sliding.

Geographic Information System (GIS) techniques have large capabilities for storing, multiple layers analyzing very complex factors. Remote sensing techniques are very useful in preparing necessary data in landslide hazard zonation. Among many useful classifications of assessment techniques for landslide hazard, the classifications given by Mantovani et al. (1996) and Hartle'n and Viberg (1988) cover the majority.

Multivariate statistical analysis models for landslide hazard zonation were developed in Italy, mainly by Carrara (1983, 1988) and his colleagues (Carrara et al. 1990, 1991, 1992).

Rapid drawdown can occur when a river drops following a flood stage, the water level in a reservoir or canal is dropped suddenly, or the sea level drops following a storm tide. Unless pore pressures within the slope adjacent to the falling water level can dissipate quickly, the slope is subjected to higher shear stresses and potential instability (Terzaghi 1943; Lambe and Whitman 1969). In terms of effective stress, Bishop (1954, 1955) introduced a method to estimate the pore-water pressure in terms of reduction of the principal stresses and to analyze slope stability due to the removal of the water load during rapid drawdown.

\section{Study area:}

Madikeri taluk is the thickly wooded grandeur on the Western Ghats, is the most beautiful hill station of Karnataka. It occupies an area of $1,434.4 \mathrm{~km}^{2}$ (Fig 1$)$ in the Western Ghats of southwestern Karnataka. Much of Madikeri taluk consists forest and coffee plantation. Characteristically and historically, paddy fields are found on the valley floors, with Coffee and pepper agro-forestry in the surrounding hills. The most common plantation crop is coffee, especially Coffee robusta variety.

The main river in Kodagu is the Kaveri (Cauvery), which originates at Talakaveri, located on the eastern side of the Western Ghats, and with its tributaries, drains the greater part of Kodagu district. In July and August, rainfall is intense, and there are often showers into November. Yearly rainfall may exceed 4,000 $\mathrm{mm}$ in some areas. In dense jungle tracts, rainfall reaches 3,000 to 3,800 $\mathrm{mm}$. Madikeri has an average temperature of $15^{\circ} \mathrm{C}$, ranging from 11 to $28^{\circ} \mathrm{C}$, with the highest temperatures occurring in April and May.

\section{Materials and methodologies:}

Cartosat-1 Digital Elevation Model (DEM) of version 3 obtained from National Remote Sensing Centre (NRSC). DEM is processed in ArcGIS 10.3 version software to achieve Slope, slope aspect, drainage network and drainage density using spatial analyst tools. 


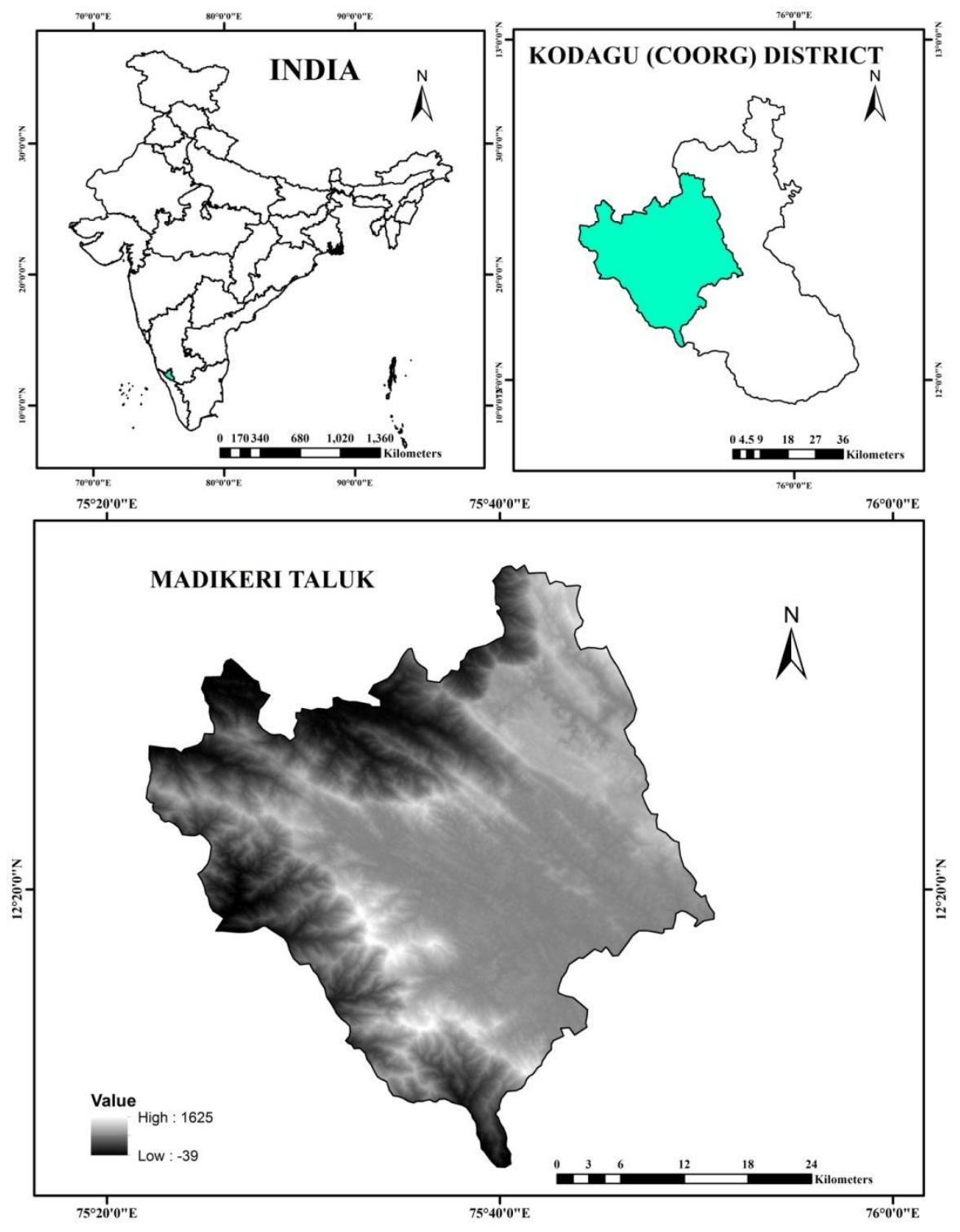

Figure 1: Study area

Geological and structural data is obtained from Geological Survey of India and demarcated the three different types of litho units.

Soil data is obtained from National Bureau of Soil Survey and Land use Planning (NBSS and LUP) and is processed in ArcGIS to mark the different types of soil.

Geomorphology and land Use \& land Cover is obtained from Karnataka State Remote Sensing Application Centre (KSRSAC), Bengaluru. 
Daily Rainfall data from Karnataka State Natural Disaster Monitoring Centre (KSNDMC), Bengaluru is collected to calculate the percentage departure as well as intensity of rainfall pattern. Fig 2 shows the flowchart of the study.

Cartosat-1 stereo datasets are proved in high accuracy compared to SRTM and ASTERDEM (Muralikrishnan et al. 2013) and tile extent/spatial extent of $1^{\circ} \times 1^{\circ}$ from $X$ in $75-76 \mathrm{E}$ and $Y$ in $12-13 \mathrm{~N}$ is used to achieve drainage network. The extracted slope, aspect, stream network, and drainage density are projected to the regional projection (WGS_1984_UTM_Zone_43 N).

The unique characteristics of CartoSAT-1 stereo data and planned products are given below:

$\begin{array}{ll}\text { Name of the dataset: } & \text { C1_DEM_16B_2005-2014_v3_R-1_75E12N_d43v } \\ \text { Theme: } & \text { Terrain } \\ \text { Spheroid/datum: } & \text { GCS, WGS-1984 } \\ \text { Original source: } & \text { Cartosat-1 PAN (2.5 m) stereo data } \\ \text { Resolution: } & 1 \text { arc s }(32 \mathrm{~m}) \\ \text { Sensor: } & \text { PAN }(2.5 \mathrm{~m}) \text { stereo data } \\ \text { File format: } & \text { Geotiff } \\ \text { Bits per pixel: } & 16 \text { bit }\end{array}$

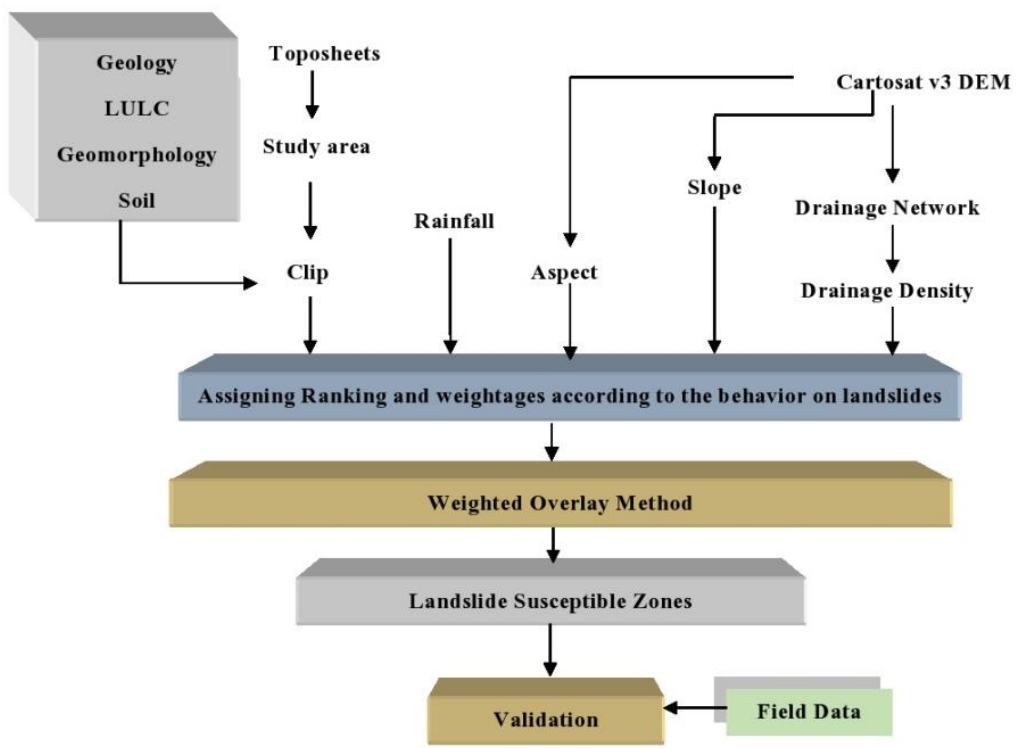

Figure 2: Flowchart of the study 


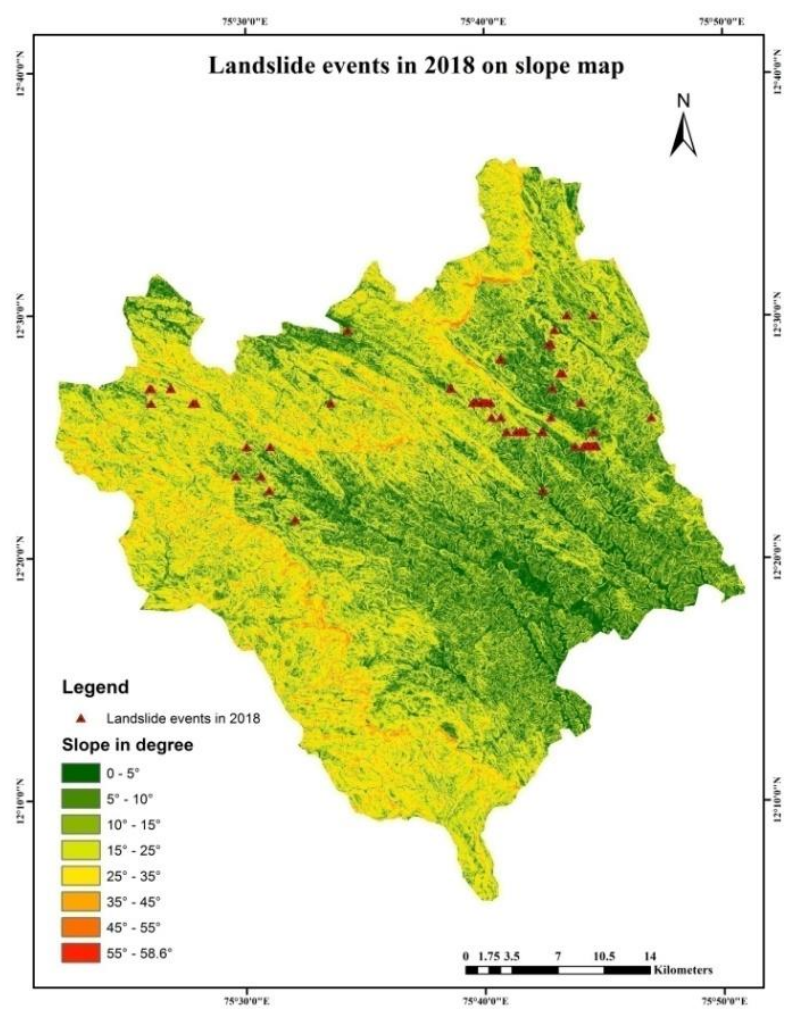

Figure 3: Spatial distribution of landslide events in 2018 on slope map

\section{Extraction of Drainage network}

The steps are as given below to obtain watershed and stream orders derived from Cartosat-1 DEM are as follows:

- Fill the sinks in the Cartosat - 1 DEM

- Apply the flow direction function to the filled Cartosat - 1 DEM

- Apply the flow accumulation function on the flow direction grid

- Apply the logarithmic accumulation function from raster calculator

- Apply the conditional function from raster calculator

- Apply a threshold condition to the conditioned flow direction grid

- Obtain a streams grid from the threshold condition grid

- Obtain the stream links grid

- Obtain watersheds grid from the streams grid

- Vectorise the streams grid

- Vectorise the watershed grid.

\section{Results and Discussions:}

\section{$\underline{\text { Slope and Aspect }}$}


Slope is formally described by a plane at a tangent to a point on the surface. Slope has two components. Gradient: the maximum rate of change of the elevation of the plane (the angle that the plane makes with a horizontal surface) and Aspect: the direction of the plane with respect to some arbitrary zero (usually north!)

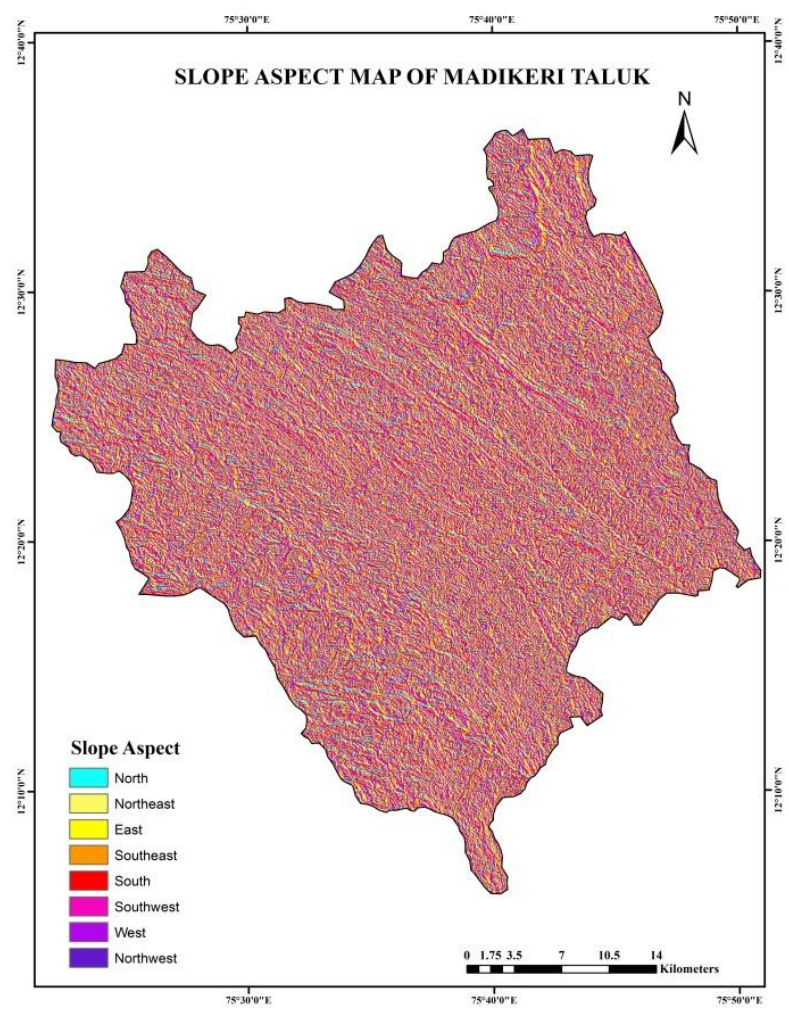

Figure 4: Spatial distribution slope Aspect map

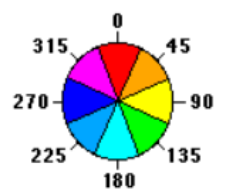

Figure 5: Aspect directions

Slope constitutes a very important parameter in landslide hazard zonation studies, since its stability form the basis for the frequency and intensity of hazard study. Particularly, in the hilly region the chance of occurrences of landslides hazards is more in higher slopes. The slope and the aspect are extracted from the Cartosat 1 version 3 data by processing in the arcgis software.

Table 1: Classification of Slope

\begin{tabular}{|c|c|c|l|}
\hline SI No & Class & Symbol & Description \\
\hline 1 & $0-5^{\circ}$ & A & Very Gentle \\
\hline 2 & $5^{\circ}-10^{\circ}$ & B & Gentle \\
\hline 3 & $10^{\circ}-15^{\circ}$ & C & Moderate \\
\hline 4 & $15^{\circ}-25^{\circ}$ & D & Moderately Steep \\
\hline
\end{tabular}




\begin{tabular}{|c|c|c|l|}
\hline 5 & $25^{\circ}-35^{\circ}$ & E & Steep \\
\hline 6 & $35^{\circ}-45^{\circ}$ & F & High Steep \\
\hline 7 & $45^{\circ}-58.6^{\circ}$ & G & Very high Steep \\
\hline
\end{tabular}

In the study area slope varies from 0 to $59^{\circ}\left(\mathrm{Fig}\right.$. 3). The current slope map is divided 7 categories $5^{\circ}$ interval from 0 to $15^{\circ}$ and $10^{\circ}$ interval from 15 to $55^{\circ}$. The scores of these sub-variables were multiplied with the analogous weightage 25 of the slope layer. Most of the landslide events during 2018 are occurred in steep slope to very high steep slope zones and few slides are in river sections due to high pour water pressure.

Table 2: Classification of Slope Aspect

\begin{tabular}{|c|c|c|}
\hline SI No & Class & Symbol \\
\hline 1 & North $(0-22.5)$ & 1 \\
\hline 2 & NE $(22.5-67.5)$ & 2 \\
\hline 3 & East $(67.5-112.5)$ & 3 \\
\hline 4 & SE $(112.5-157.5)$ & 4 \\
\hline 5 & $\mathrm{~S}(157.5-202.5)$ & 5 \\
\hline 6 & $\mathrm{SW}(202.5-247.5)$ & 6 \\
\hline 7 & $\mathrm{~W}(247.5-292.5)$ & 7 \\
\hline 8 & $\mathrm{NW}(292.5-337.5)$ & 8 \\
\hline 9 & $\mathrm{~N}(337.5-359.9)$ & 9 \\
\hline
\end{tabular}

Aspect identifies the downslope direction of the maximum rate of change in value from each cell to its neighbors. It can be thought of as the slope direction. The values of each cell in the output raster indicate the compass direction that the surface faces at that location. It is measured clockwise in degrees from 0 (due north) to 360 (again due north), coming full circle. Flat areas having no downslope direction are given a value of -1 .

Aspect is very important in any landslide susceptible zonation mapping. Aspect of the study area was divided into nine categories (Fig 4) and multiplied with the corresponding weightage 10.

The value of each cell in an aspect dataset indicates the direction the cell's slope faces.

Conceptually, the Aspect tool fits a plane to the z-values of a 3 x 3 cell neighborhood around the processing or center cell. The direction the plane faces is the aspect for the processing cell.

\section{Drainage and Density}

Drainage network is extracted from Dem (Fig 6 ) and majorly dendritic type of drainages is present in the study area. Drainage density is the total length of all the streams and rivers in a drainage basin divided by the total area of the drainage basin. It is a measure of how well or how poorly a watershed is drained by stream 
channels. It is equal to the reciprocal of the constant of channel maintenance and equal to the reciprocal of two times the length of overland flow.

Drainage density depends upon both climate and physical characteristics of the drainage basin. Soil permeability (infiltration difficulty) and underlying rock type affect the runoff in a watershed; impermeable ground or exposed bedrock will lead to an increase in surface water runoff and therefore to more frequent streams. Rugged regions or those with high relief will also have a higher drainage density than other drainage basins if the other characteristics of the basin are the same.

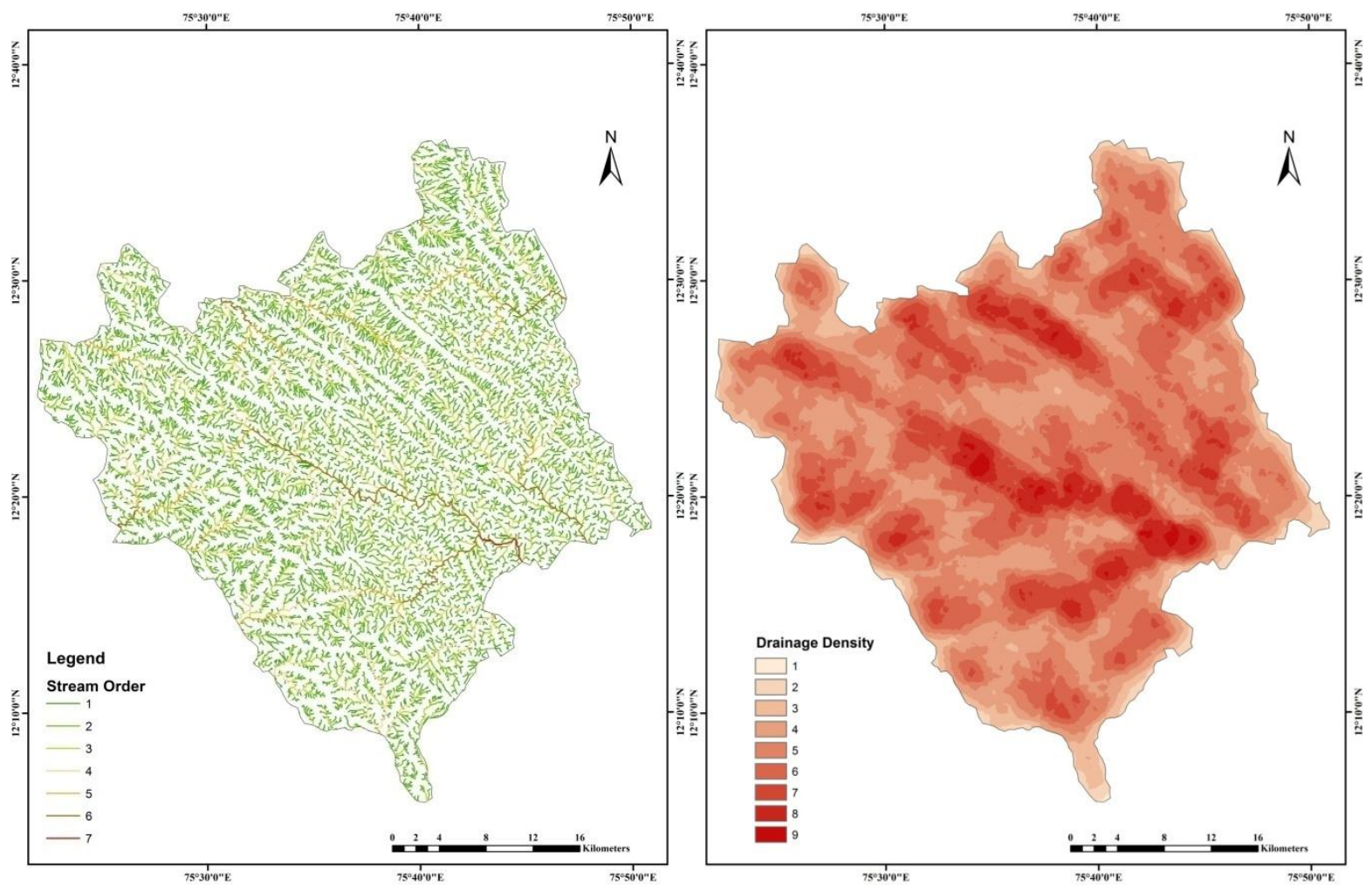

Figure 6: Spatial distribution of drainage network Figure 7: Spatial distribution of drainage density

Table 3: Classification of drainage density

\begin{tabular}{|c|c|c|}
\hline SI No & Drainage Density & Classes \\
\hline 1 & $0-56$ & 1 \\
\hline 2 & $56-112$ & 2 \\
\hline 3 & $112-169$ & 3 \\
\hline 4 & $169-225$ & 4 \\
\hline 5 & $225-281$ & 5 \\
\hline 6 & $281-338$ & 6 \\
\hline 7 & $338-394$ & 7 \\
\hline 8 & $394-450$ & 8 \\
\hline 9 & $450-507$ & 9 \\
\hline
\end{tabular}


Drainage density (Fig 7) can affect the shape of a river's hydrograph during a rain storm. Rivers that have a high drainage density will often have a more 'flashy' hydrograph with a steep falling limb. High densities can also indicate a greater flood risk.

High drainage densities also mean a high bifurcation ratio. High drainage density is the resultant of weak or impermeable subsurface material, sparse vegetation and mountainous relief. Low drainage density leads to coarse drainage texture, while high drainage density leads to fine drainage texture (Strahler 1964). On the one hand, the $D_{d}$ is a result of interacting factors controlling the surface runoff; on the other hand, it is itself influencing the output of water and sediment from the drainage basin (Ozdemir and Bird 2009).

\section{Geology}

The study area is made up of Charnockite (2500 m.y.), peninsular gneissic complex - I (3000 - 2900 m.y.) and sargur rocks are the main underlying geology (Fig 8). The pyroxene granulite of Charnockite group is postulated to be archean to proterozoic in age, tonalite-trondjhemite-granodiorite of PGC-I group of archean in age and high grade schists and ultramafites of Sargur complex group of archean in age (Geological Survey of India, Misc Pub.No.30 Part-VII $3^{\text {rd }}$ revised edition, 2014). Majority of the rock types are prone to weathering. Gneissic complex consists mainly of feldspar and mica minerals that weather comparatively swiftly as compared to quartz.

Slope material may be composed of rock mass or soils or both. In the case of rocks, rock type and its intact rock strength governs the potential for its general instability. The erodibility of rock is highly influenced by the strength of the rock (Raghuvanshi, T.K., Ibrahim, J., Ayalew, D., et al., 2014). 


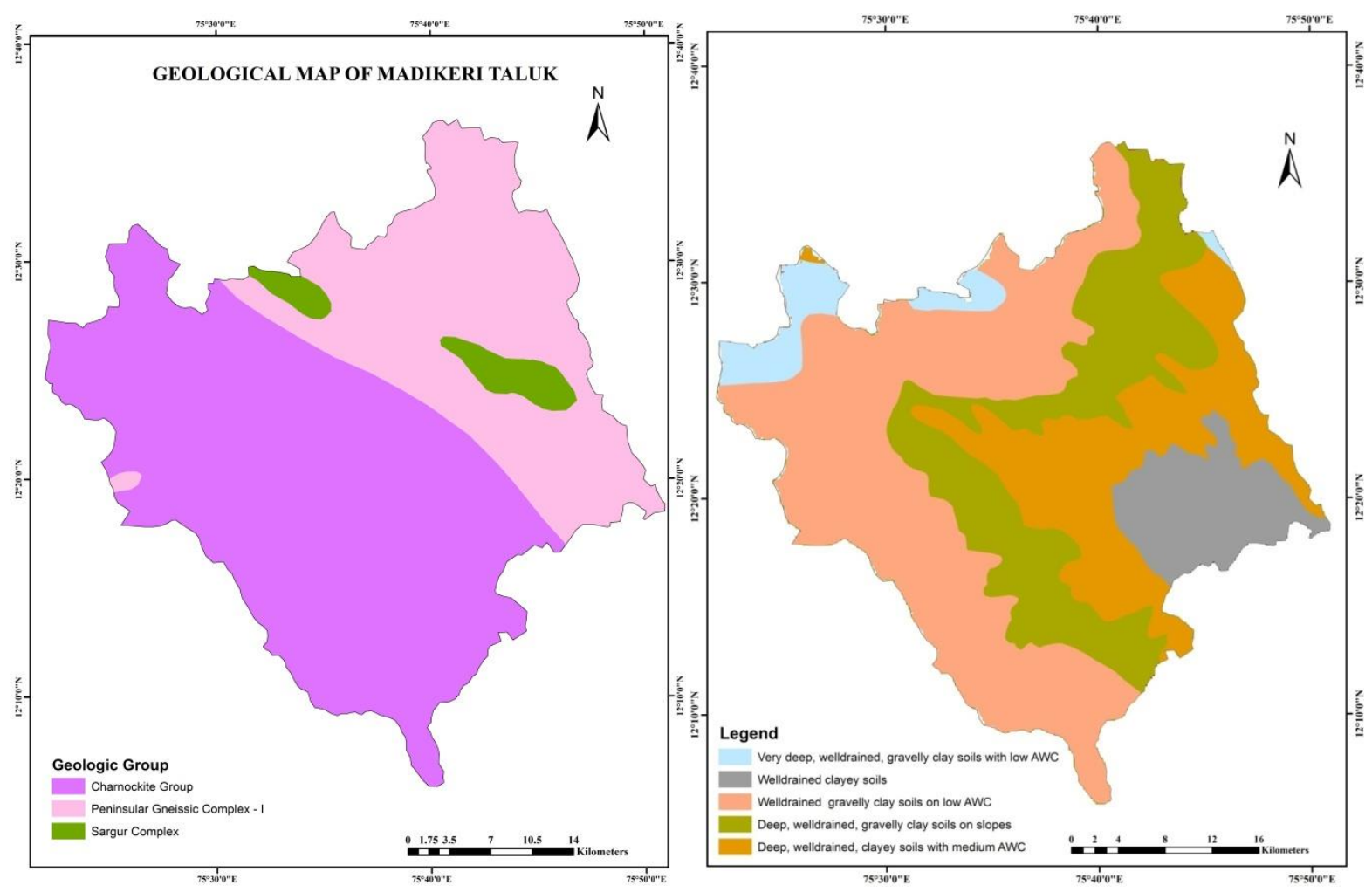

Figure 8: Spatial distribution of geology Figure 9: Spatial distribution of Soil

The minerals of granitic/gneissic rock weather according to this sequence: plagioclase feldspar, biotite, potassium feldspar, muscovite, and quartz. Biotite is a particularly active agent in the weathering process of granite. It expands to form hydrobiotite that helps disintegrate the rock into grus (Grus is an accumulation of angular, coarse-grained fragments (particles of sand and gravel) resulting from the granular disintegration by the processes of chemical and mechanical weathering of crystalline rocks (most notably granitoids).) (Wahrhaftig, 1965; Isherwood and Street, 1976). The feldspars break down by hydrolysis and hydration into clays and colloids, which may migrate from the rock. Muscovite and quartz grains weather slowly and usually form the skeleton of saprolite which is a precursor to laterite. The biotite and feldspar weather first, causing micro fractures and pores to form. Ground water can then leach out the resulting colloids and clays.

\section{$\underline{\text { Soil }}$}

Soil forms the uppermost part of the earth crust and it is expected that various soil characteristics like depth, surface texture, plays significant role in causing landslide in the area. The soil type may also define its potential for its relative instability. The colluvial soils relatively possess weak shear strength as it may contain loose aggregates of fragmented rock of varied dimensions in a matrix of sandy silty clay soils. In contrast residual soils are well consolidated soils and relatively possess better shear strength. Soil has been 
classified into five different categories, according to their depth and texture (Brady and Weil 2007). The study area comprises of five types of soils (Fig. 9).

The rate and amount of top soil formation is more and also the soil being characterized as very fine grained clayey (Photo. 1 and 2) and clayey skeletal soil (Photo.3and 4). Accumulation of heavy rainfall the top soil got heavily saturated thus increase in self weight of the soil mass. Also the layer beneath the top soil is clay layer which again has less resistance to sliding.

Table 4: Classification of soils

\begin{tabular}{|c|c|c|c|}
\hline $\begin{array}{l}\text { Sl } \\
\mathbf{N} \\
\mathbf{0}\end{array}$ & $\begin{array}{l}\text { Mapping } \\
\text { Unit }\end{array}$ & Description & Soil Taxonomy \\
\hline 1 & 79 & $\begin{array}{l}\text { Deep, welldrained, clayey soils on dissected hills } \\
\text { and valleys, with moderate erosion; associated } \\
\text { with very deep, welldrained clayey soils }\end{array}$ & $\begin{array}{l}\text { - Fine, kaolinitic, Typic } \\
\text { Kanhaplustalfs } \\
\text { - Fine, mixed, Typic Argiustolls }\end{array}$ \\
\hline 2 & 81 & $\begin{array}{l}\text { Deep, welldrained, gravelly clay soils with low } \\
\text { AWC, strongly gravelly in the sub soil on high } \\
\text { hill ranges with steep slopes ; associated with } \\
\text { deep welldrained, clayey soils, severely eroded. }\end{array}$ & $\begin{array}{l}\text { - Clayey-skeletal, kaolinitic, } \\
\text { Kandic Paleustalfs } \\
\text { - Clayey, kaolinitic, Paleustults }\end{array}$ \\
\hline 3 & 82 & $\begin{array}{l}\text { Deep, welldrained, gravelly clay soils on slopes of } \\
\text { steeply sloping high hill ranges, with moderate } \\
\text { erosion, associated with; Moderately shallow, } \\
\text { welldrained, gravelly clay soils with low AWC, } \\
\text { strongly gravelly in the subsoil. }\end{array}$ & $\begin{array}{l}\text { - Clayey-skeletal, kaolinitic, } \\
\text { Kandic Paleustalfs } \\
\text { - Clayey-skeletal, kaolinitic, } \\
\text { Ustic Haplohumults }\end{array}$ \\
\hline 4 & 85 & $\begin{array}{l}\text { Deep, welldrained, clayey soils with medium } \\
\text { AWC on foothill slopes, with severe erosion, } \\
\text { associated with; Moderately deep, welldrained, } \\
\text { loamy soils }\end{array}$ & $\begin{array}{l}\text { - Fine, kaolinitic, Kandic } \\
\text { Paleustalfs } \\
\text { - Fine-loamy, mixed, } \\
\text { Kanhapplic Rodustalfs }\end{array}$ \\
\hline 5 & 109 & $\begin{array}{l}\text { Very deep, welldrained, gravelly clay soils with } \\
\text { low AWC on low hill ranges, with moderate } \\
\text { erosion; associated: Moderately deep, somewhat } \\
\text { excessively drained, gravelly clay soils. }\end{array}$ & $\begin{array}{l}\text { - Clayey-skeletal, kaolinitic, } \\
\text { ustic Hapohumults } \\
\text { - Clayey-skeletal, kaolinitic, } \\
\text { Ustic Kanhaplohumults }\end{array}$ \\
\hline & & & AWC: Available water Capacity \\
\hline
\end{tabular}

Particle-size classes in vertical sequences within a profile (Fig 10) that differ significantly in pore-size distribution, so that movement and retention of water are seriously affected, are recognized as strongly contrasting particle size classes (Richard L. Handy and Thomas E. Fenton). 

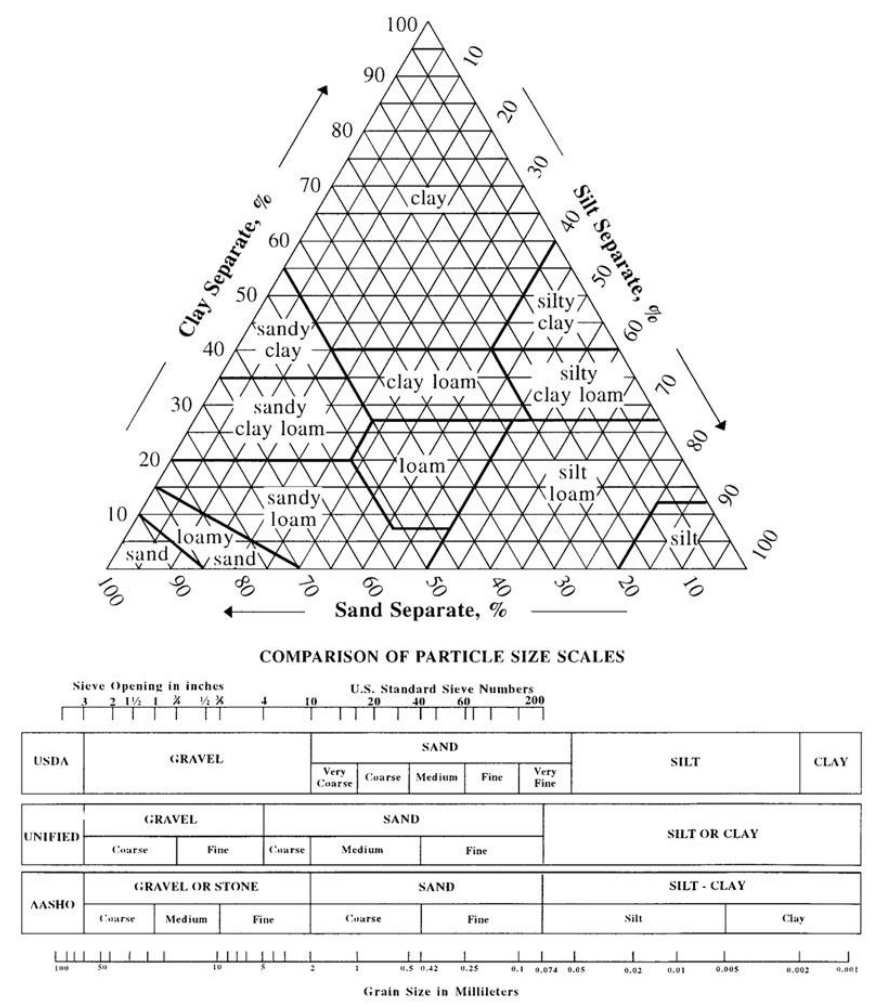

Figure 10: Soil texture triangle showing the USDA classification system based on grain size

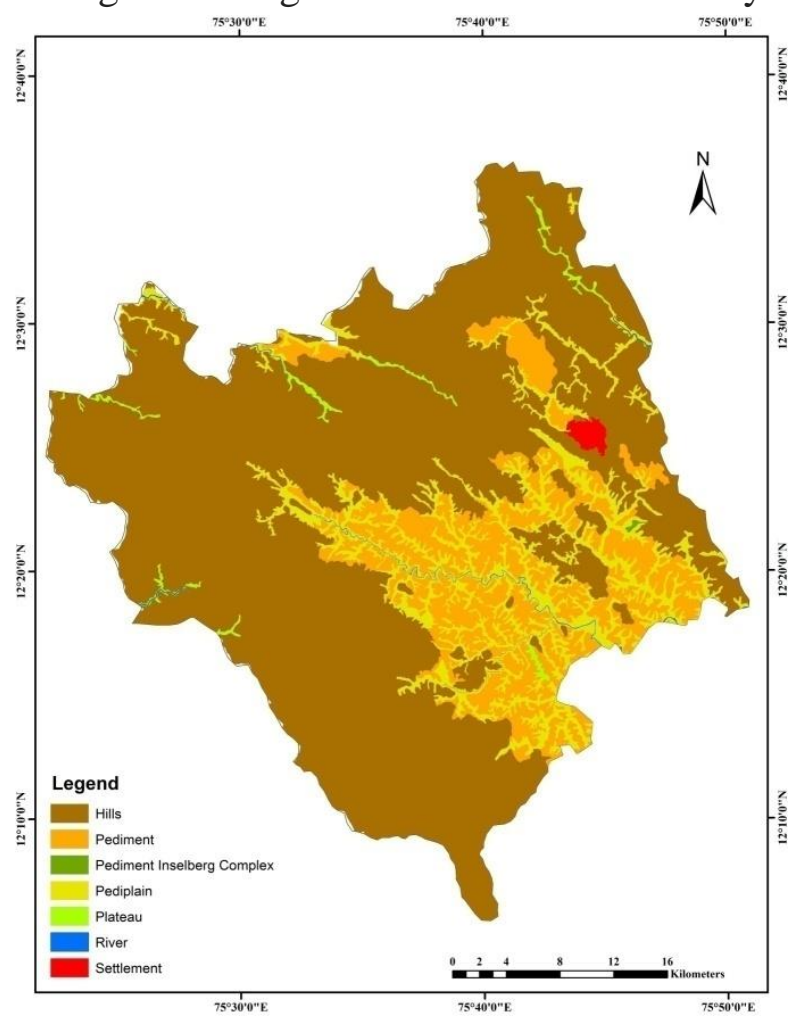

Figure 11: Spatial distribution of geomorphology 


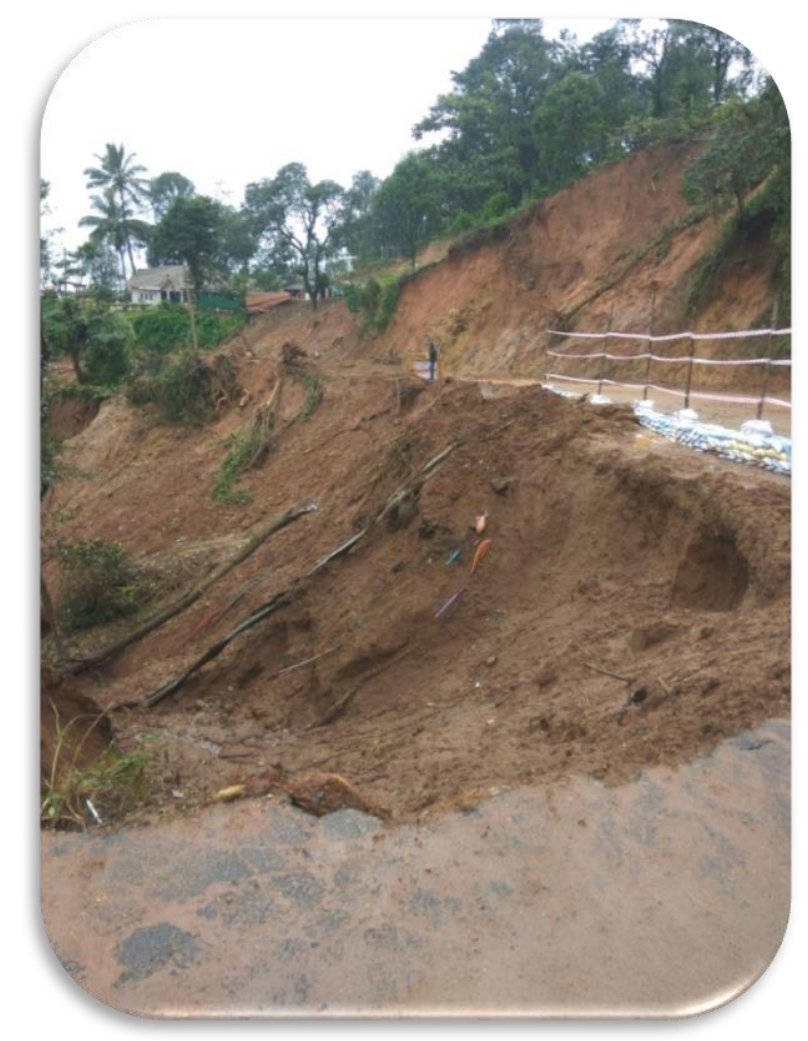

Photo 1: Vertical slope cutting without retaining structures 


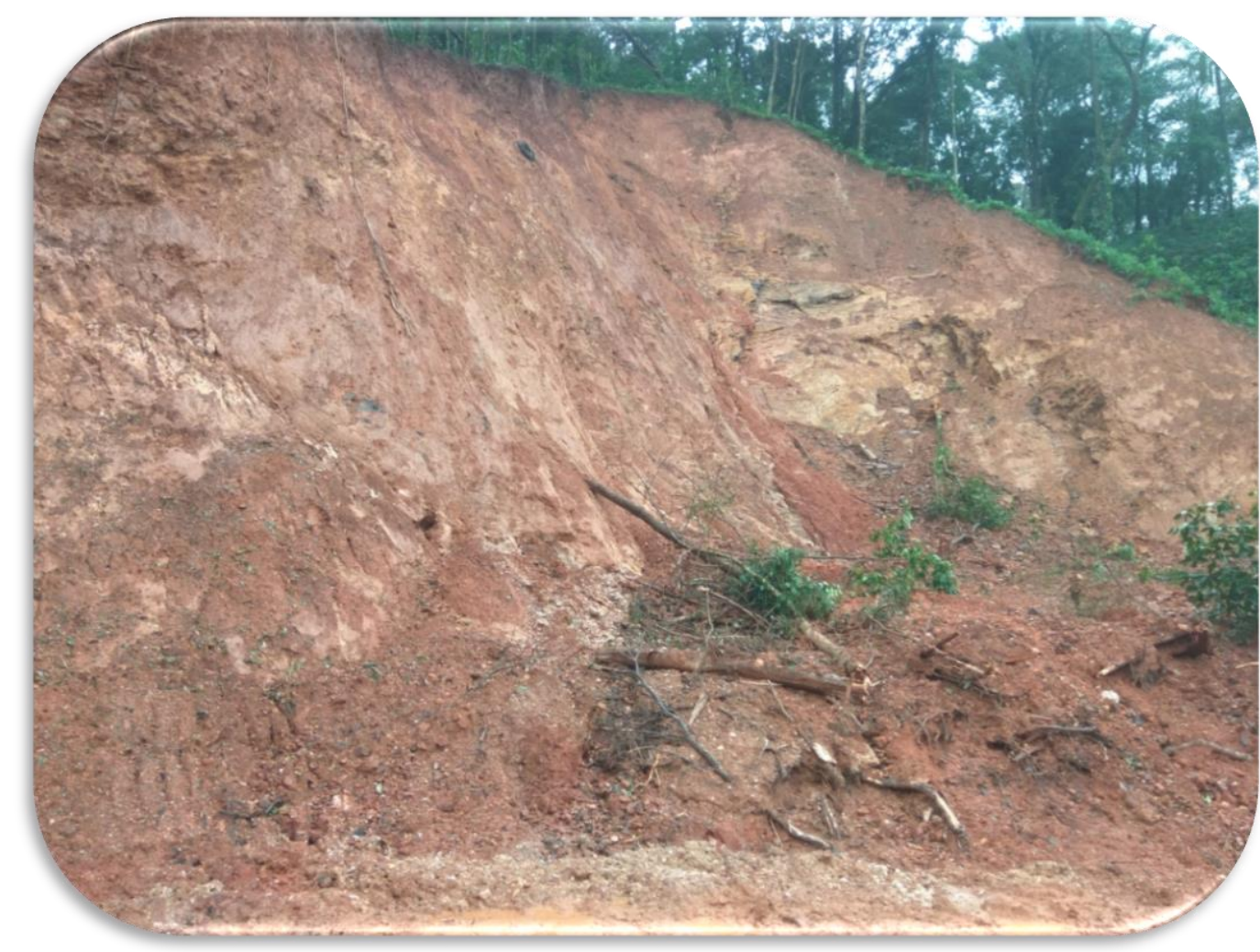

Photo 2: Highly weathered gneissic rock presence of fractures and clayey soil 


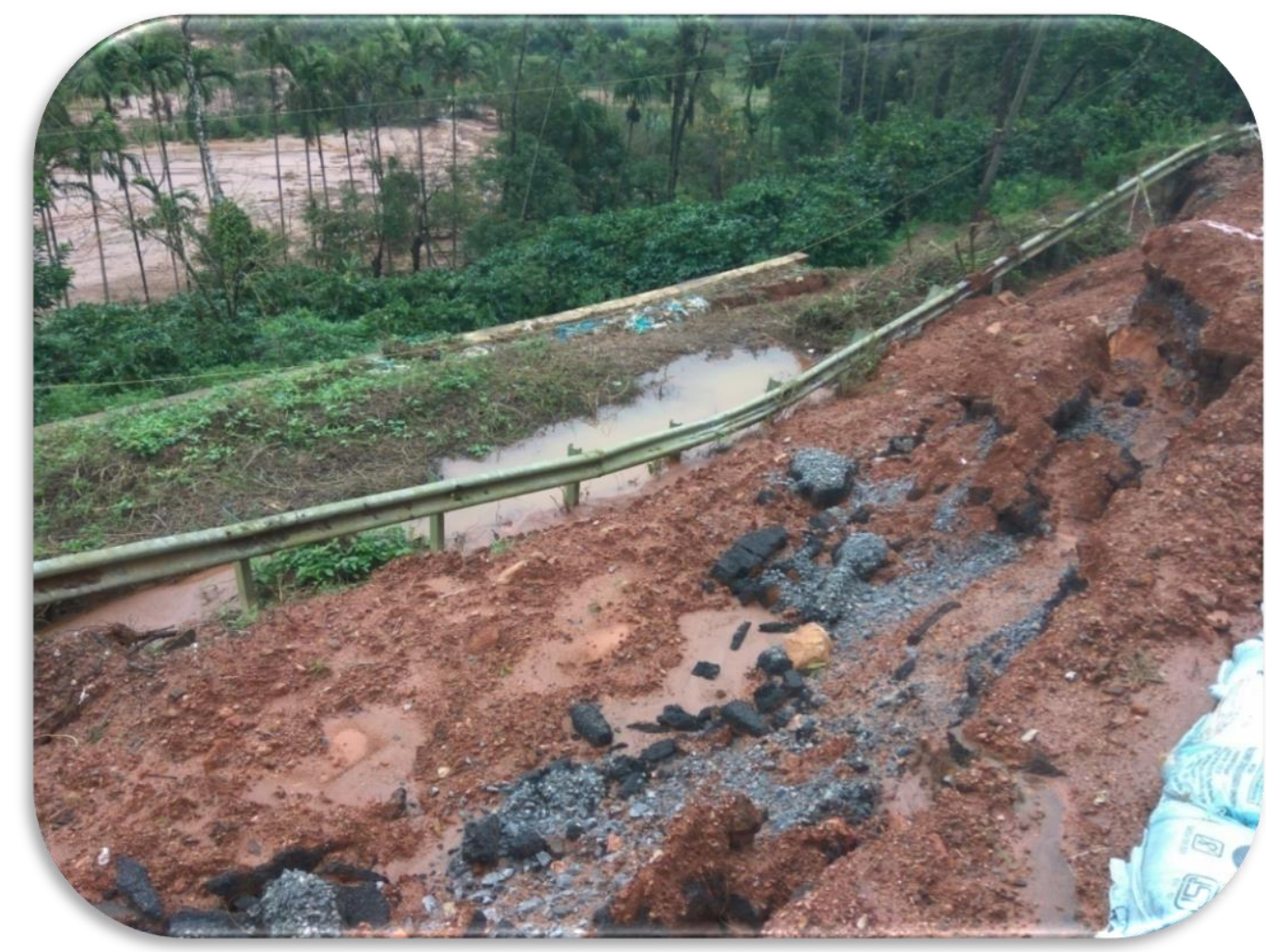

Photo 3: Subsided road near to retaining structure

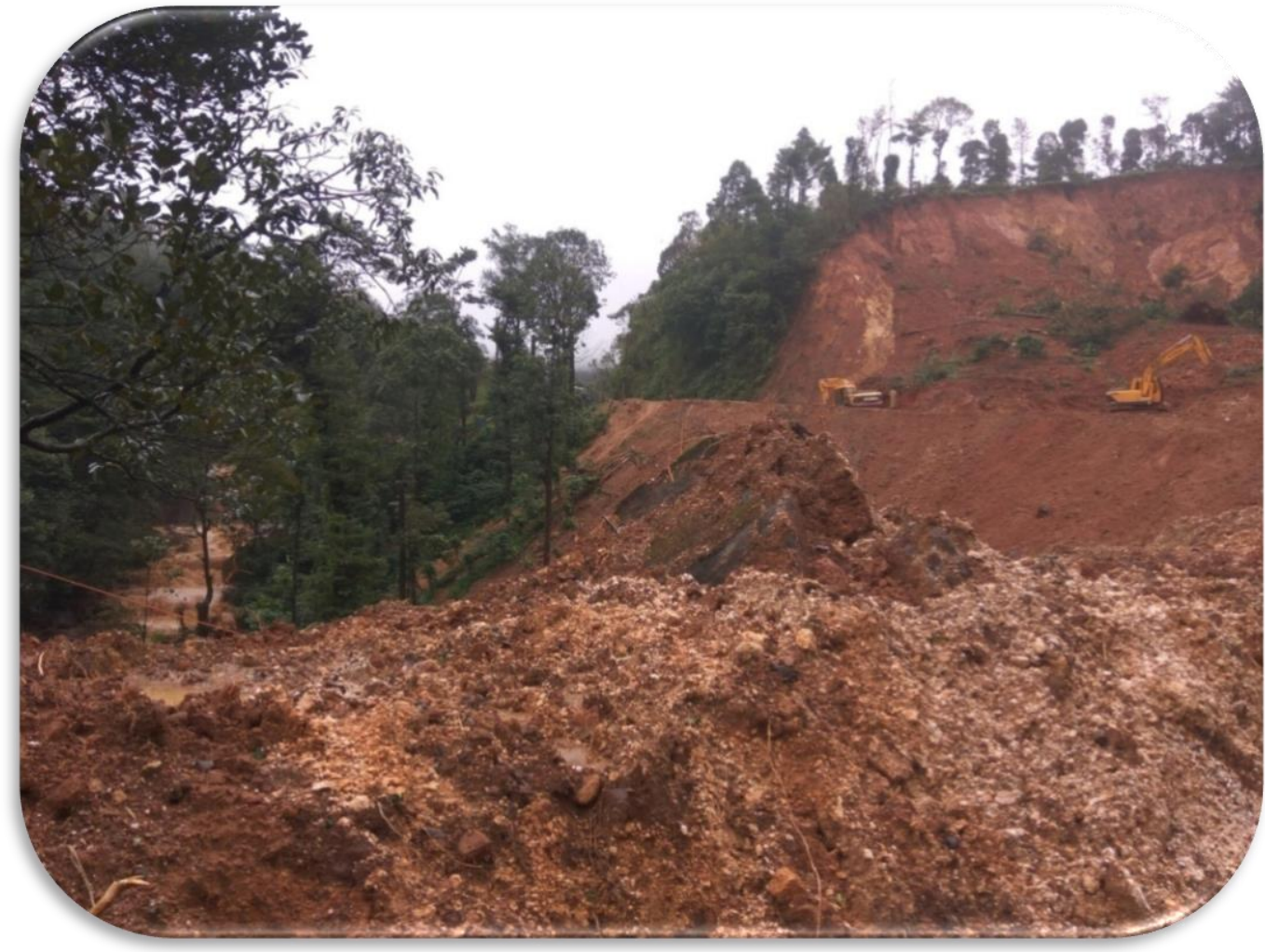


Photo 4: Gravelly clayey skeletal soil type

\section{Geomorphology}

Geomorphology replicates different landforms as well as structures. Several features like hills, settlements are vulnerable for the occurrence of landslides. These units are deciphered from the remote sensing data (Fig: 11). The major geomorphological features are denudational hills, pediplain, plateau, dissected pediments and Inselberg complex.

\section{Denudational Hills (DH)}

Denudational hills are formed due to the degree of difference erosion and weathering. They engage the northern, western and southern part of the study area. The vulnerability of landslides is more in these zones.

\section{Pediplain}

Pediplain is developed as an outcome of continuous processes of sedimentation. The latitudinal variants are comparatively more for rolling plain to the extent of 5-10 m. These areas are depicts as nearly level terrain with gentle slope. The area is underlain by relatively thick weathered material. The landslide occurrence in these areas is illustrates as low to very low depending upon the soil stability.

\section{Plateau}

Flat topped and arcuate are presenting distinct trends. Encompasses thin layer of soil, which varies from place to place, sparse vegetation weathering is also found at some places.

\section{Dissected pediment}

Any relatively flat surface of bedrock (exposed or veneered with alluvial soil or gravel) that occurs at the base of a mountain or as a plain having no associated mountain. Pediments, sometimes mistaken for groups of merged alluvial fans, are most conspicuous in basin-and-range-type desert areas throughout the world.

\section{Land Use and Land Cover}

The Land Use and Land Cover (LULC) data files describe the vegetation, water, natural surface, and cultural features on the land surface. Nonetheless, lu/lc provides a very valuable method for determining the extents of various land uses and cover types, such as urban, forested, scrubland, agriculture, etc. Land use/land cover data are most commonly in a raster or grid data structure, with each cell having a value that corresponds to a certain classification. This structure allows for creating summary tables and performing suitability analyses. The different types of land use/land cover are shown in Fig 12. 


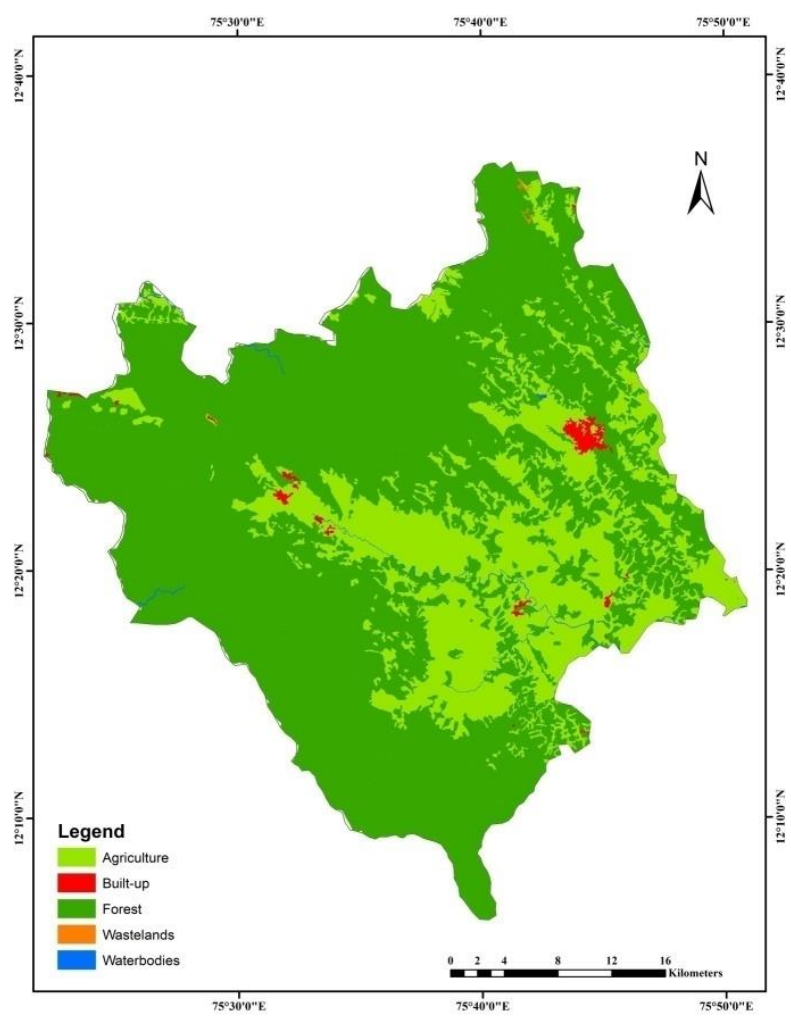

Figure 12: Spatial distribution of land use and land cover

\section{Agricultural land}

It is the land chiefly used for farming and for production of food, fodder and other commercial and horticultural crops. It includes irrigated, unirrigated, plantations etc. They are further subdivided into kharif unirrigated; double crop and plantations.

\section{Forest land}

It is an area surrounded by the notified forest limit bearing an association predominantly of trees and other vegetative. Forest lands are going to stop the erosion process from surface runoff and it allows water for infiltration to boost groundwater level.

\section{Built-up land/settlement}

It is an area of human occupancy residential due to non-agricultural use and has encircle of buildings, transport, and communication, utilities in union with water, vegetation and vacant lands. All the settlements in the study area are delineated. Major portion of the study area comprises forest land and agriculture land. Chances of landslides are more in this area, due to absence of retaining walls. 


\section{Rainfall analysis}

During monsoons of 2018, Madikeri has experienced very heavy rainfall. Cumulative rainfall in pre monsoon of 2018(1 $1^{\text {st }}$ January to $31^{\text {st }}$ may 2018) will be $534 \mathrm{~mm}$ (Table 5a) against to the normal rainfall $331 \mathrm{~mm}$ and the $\%$ departure is $+62 \%$. The pre monsoon itself has recorded high rainfall I the month of May 2018. Cumulative rainfall in the Madikeri taluk from $1^{\text {st }}$ June 2018 to $31^{\text {st }}$ august 2018 is $4157 \mathrm{~mm}$ (Table $5 \boldsymbol{b}$ ) against to the normal rainfall of $3085 \mathrm{~mm}$ and the percentage departure is $+35 \%$ more that the average annual rainfall.

Table 5a: Rainfall pattern of Madikeri taluk and sub-taluks

\begin{tabular}{|c|c|c|c|c|c|c|c|c|c|c|c|c|}
\hline \multirow{2}{*}{ Taluk/Hobli } & \multicolumn{3}{|c|}{$\begin{array}{c}\text { 1st January to 31st May } \\
2018\end{array}$} & \multicolumn{3}{|c|}{ JUNE 2018} & \multicolumn{3}{|c|}{ JULY 2018} & \multicolumn{3}{|c|}{ August 2018} \\
\hline & $\begin{array}{c}\text { Normal } \\
(\mathrm{mm})\end{array}$ & $\begin{array}{l}\text { Actual } \\
(\mathrm{mm})\end{array}$ & $\%$ DEP & $\begin{array}{l}\text { Normal } \\
(\mathrm{mm})\end{array}$ & $\begin{array}{l}\text { Actual } \\
(\mathrm{mm})\end{array}$ & $\%$ DEP & $\begin{array}{l}\text { Normal } \\
(\mathrm{mm})\end{array}$ & $\begin{array}{l}\text { Actual } \\
(\mathrm{mm})\end{array}$ & $\%$ DEP & $\begin{array}{c}\text { Normal } \\
(\mathrm{mm})\end{array}$ & $\begin{array}{l}\text { Actual } \\
(\mathrm{mm})\end{array}$ & $\%$ DEP \\
\hline MADIKERI TALUK & 331 & 534 & 62 & 917 & 1176 & 28 & 1286 & 1542 & 20 & 882 & 1439 & 63 \\
\hline MADIKERI HOBLI & 268 & 496 & 85 & 809 & 789 & -2 & 805 & 1344 & 67 & 789 & 1438 & 82 \\
\hline BHAGAMANDALA HOBLI & 358 & 581 & 62 & 1195 & 1438 & 20 & 1905 & 1741 & -9 & 1148 & 1460 & 27 \\
\hline NAPOKLU HOBLI & 378 & 508 & 34 & 601 & 1461 & 143 & 1012 & 1569 & 55 & 569 & 1441 & 153 \\
\hline SAMPAJE HOBLI & 307 & 549 & 79 & 1036 & 845 & -18 & 1280 & 1434 & 12 & 987 & 1390 & 41 \\
\hline
\end{tabular}

Well documented studies that have revealed a close relationship between rainfall intensity and activation of landslides include those from California (Campbell 1975; Ellen et al 1988), North Carolia (Gryta and Bartholomew 1983; Neary and Swift 1987), Virginia (Kochel 1987; Gryta and Bartholomew 1989; Jacobson et al 1989), Puerto Rico (Jibson 1989; Simon et al 1990; Larsen and Torres Sanchez 1992), and Hawaii (Wilson et al 1992; Ellen et al 1993).

Table 5b: Rainfall pattern of Madikeri taluk and sub-taluks

\begin{tabular}{|c|c|c|c|c|c|c|}
\hline \multirow[t]{2}{*}{ Taluk/Hobli } & \multicolumn{3}{|c|}{$\begin{array}{ll}\text { South West Monsoon } \\
2018 \quad \begin{array}{l}\text { (1st June to 31st } \\
\text { August) }\end{array}\end{array}$} & \multicolumn{3}{|c|}{$\begin{array}{l}\text { Cumulative Rainfall } \\
\text { pattern 1st January to } \\
\text { 31st August } 2018\end{array}$} \\
\hline & $\begin{array}{c}\text { Normal } \\
(\mathrm{mm})\end{array}$ & $\begin{array}{c}\text { Actual } \\
(\mathrm{mm})\end{array}$ & $\%$ DEP & $\begin{array}{c}\text { Normal } \\
(\mathrm{mm})\end{array}$ & $\begin{array}{c}\text { Actual } \\
(\mathrm{mm})\end{array}$ & $\% \mathrm{DEP}$ \\
\hline MADIKERI TALUK & 3085 & 4157 & 35 & 3416 & 4692 & 37 \\
\hline MADIKERI HOBLI & 2403 & 3571 & 49 & 2671 & 4067 & 52 \\
\hline BHAGAMANDALA HOBLI & 4247 & 4639 & 9 & 4605 & 5220 & 13 \\
\hline NAPOKLU HOBLI & 2182 & 4471 & 105 & 2561 & 4979 & 94 \\
\hline SAMPAJE HOBLI & 3302 & 3670 & 11 & 3610 & 4218 & 17 \\
\hline
\end{tabular}

\section{Application of Weightage Overlay Method (WOM)}


Landslide occurrence is determined from landslide related factor and the future landslide can occur in the same condition with past landslide. Based on the assumption using probability method, the relationship between areas with landslide occurrences and landslide related factors could be distinguished from the relationship between area without occurrences of landslide and landslide related factors. To present the distinction quantitatively, the weightage overlay method was used for this study. The analysis and calculation processes in the analysis and modelling part were similar for all the parameter maps. To avoid longer time for doing the calculation and redundant task, the scripts or batch files as shown in Table 8 were used in the analysis. The weightage value shows that the most causative factor that influenced landslide occurrences is slope gradient.

Table 6: Assigned the weightage and ranks according to its behavior on landslide

\begin{tabular}{|c|c|c|c|c|}
\hline SI No & Parameter & Ranks & Category & Weights \\
\hline 1 & Slope & $\begin{array}{l}1 \\
1 \\
2 \\
3 \\
4 \\
5 \\
6 \\
7\end{array}$ & $\begin{array}{l}0-5^{\circ} \\
5-10^{\circ} \\
10^{\circ}-15^{\circ} \\
15^{\circ}-25^{\circ} \\
25^{\circ}-35^{\circ} \\
35^{\circ}-45^{\circ} \\
45^{\circ}-55^{\circ} \\
55^{\circ}-59^{\circ}\end{array}$ & $20-30$ \\
\hline 2 & Slope Aspect & $\begin{array}{l}1 \\
3 \\
5 \\
6 \\
9 \\
6 \\
5 \\
2 \\
1\end{array}$ & $\begin{array}{l}\text { North-facing } \\
\text { NE-facing } \\
\text { East-facing } \\
\text { SE-facing } \\
\text { South-facing } \\
\text { SW-facing } \\
\text { West-facing } \\
\text { NW-facing } \\
\text { North-facing }\end{array}$ & $10-15$ \\
\hline 3 & LULC & $\begin{array}{l}1 \\
2 \\
2 \\
3 \\
5\end{array}$ & $\begin{array}{l}\text { Forest } \\
\text { Agriculture } \\
\text { Waterbodies } \\
\text { Wastelands } \\
\text { Built-up }\end{array}$ & $5-10$ \\
\hline 4 & Geology & $\begin{array}{l}1 \\
2 \\
4\end{array}$ & $\begin{array}{l}\text { Charnokites } \\
\text { PGC-I } \\
\text { Sargur Complex }\end{array}$ & 5 \\
\hline 5 & Geomorphology & $\begin{array}{l}5 \\
2 \\
2 \\
4 \\
5\end{array}$ & $\begin{array}{l}\text { Hills \& Plateaus } \\
\text { Plains } \\
\text { River/Stream } \\
\text { Piedmont Zone } \\
\text { Settlement }\end{array}$ & $5-10$ \\
\hline 6 & Continuous and & 5 & $1000 \mathrm{~mm}$ & $15-25$ \\
\hline
\end{tabular}




\begin{tabular}{|c|c|c|c|c|}
\hline & $\begin{array}{c}\text { intensified } \\
\text { Rainfall }\end{array}$ & 6 & $1500 \mathrm{~mm}$ & \\
\hline 7 & Drainage Density & $\begin{array}{l}1 \\
2 \\
3 \\
4 \\
5 \\
6 \\
7 \\
8 \\
9\end{array}$ & $\begin{array}{l}0-126 \\
126-252 \\
252-378 \\
378-505 \\
505-631 \\
631-757 \\
757-884 \\
884-1010 \\
1010-1136\end{array}$ & $5-15$ \\
\hline 8 & Soil & $\begin{array}{l}2 \\
3\end{array}$ & $\begin{array}{l}\text { Welldrained clayey soils (79) } \\
\text { Welldrained gravelly clay soils } \\
\text { on low AWC (81) } \\
\text { Deep, welldrained, gravelly } \\
\text { clay soils on slopes (82) } \\
\text { Deep, welldrained, clayey soils } \\
\text { with medium AWC (85) } \\
\text { Very deep, welldrained, } \\
\text { gravelly clay soils with low } \\
\text { AWC (109) }\end{array}$ & $10-15$ \\
\hline
\end{tabular}
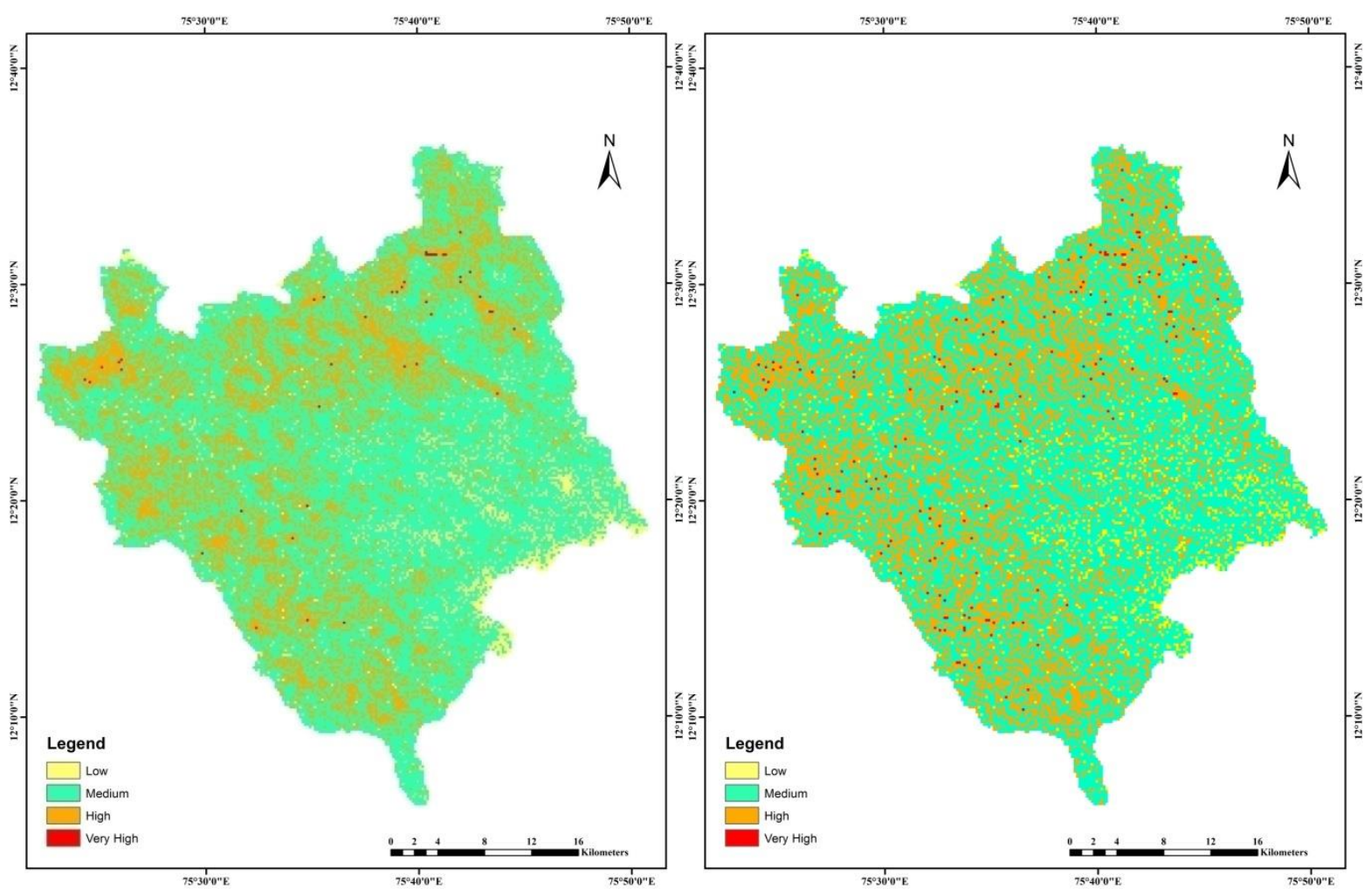
Figure 13a: Landslide susceptible map

Figure 13b: Landslide susceptible map

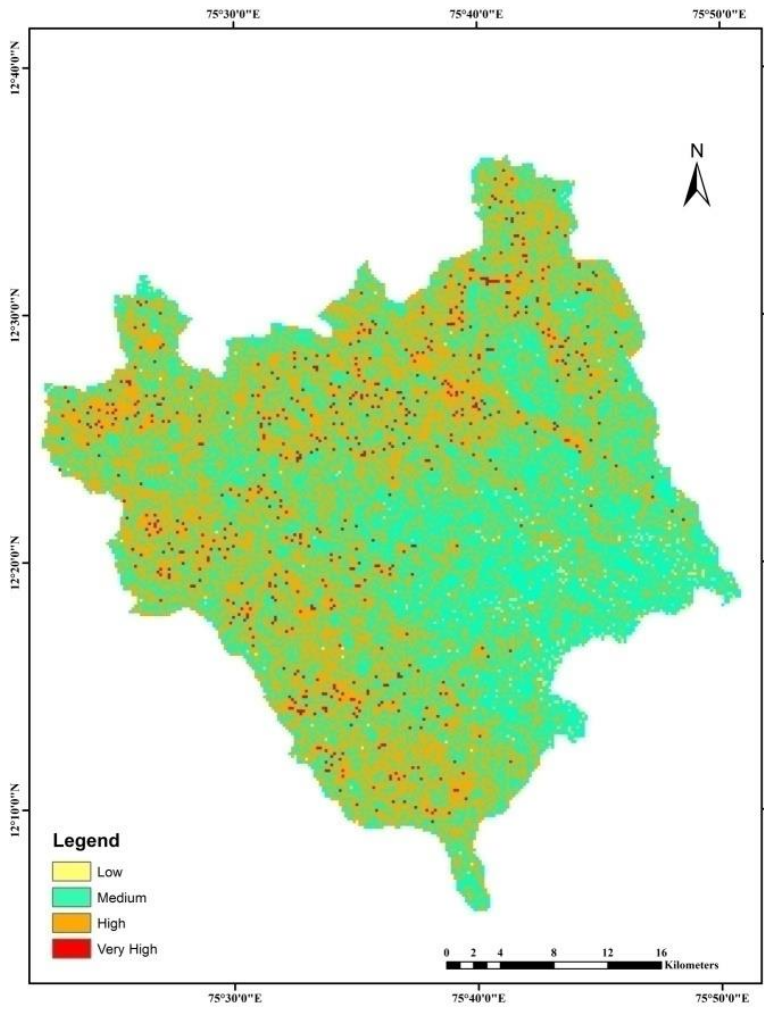

Figure 13c: Landslide susceptible map

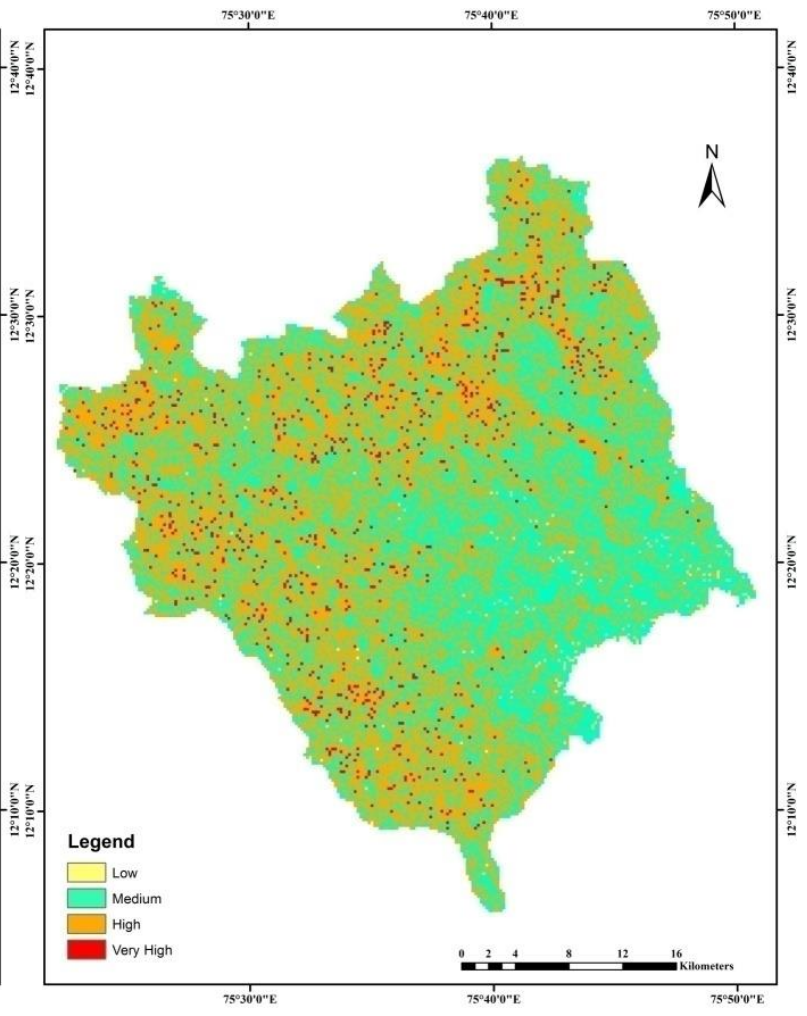

Figure 13d: Landslide susceptible map

\section{Conclusions:}

Most of landslide and subsidence were initiated between $15^{\text {th }}$ to $17^{\text {th }}$ August, 2018. Even in the moderate slopes landslides have occurred due to natural and anthropogenic activities. In pre monsoon period (Jan - May 2018) madikeri receives $534 \mathrm{~mm}$ of rainfall against $331 \mathrm{~mm}$ normal and the \% departure is $+62 \%$. During southwest monsoon (June - August) period madikeri experienced severe rainfall as high as $4157 \mathrm{~mm}$ against to the normal of $3085 \mathrm{~mm}$, which is almost $+35 \%$. Most of the landslides in 2018 are occurred in $\mathrm{NE}$ and SW of the study area. Drainage network having dendritic type and the entire landslides occurred in higher drainage density. Soil indicates that the landslide events are occurred in Deep, welldrained, gravelly clay soils on slopes. In the field investigation studies indicates that the slope modification of the natural slopes and blockage of drainages are of the major causal factors for slope failures. In the study area, high angle (vertical or near vertical) slope cut for road construction; rapid slope modification for construction of infrastructures large scale slope modification for plantation (especially coffee) are very common. Rise in the groundwater level within a short period is observed. Creation of water tanks and ponds in coffee estate are observed and these water bodies lead to more seepage within the slope. High intensity rainfall and high pour water pressure are the triggering factors for the landslide events. Rapid drawdown of groundwater level is also notable factor. Cumulative rainfall factor of $500 \mathrm{~mm}$ interval from $3000 \mathrm{~mm}$ to $4500 \mathrm{~mm}$ is assigned 
higher value of ranking and weightages to know susceptible scenario in the study area. Landslide susceptible zones are obtained as Figs. 13a, 13b, 13c and 13d and are classified as low, moderate, high and very high susceptible zones. Above normal cumulative rainfall with high intensity in the elevated slopes, and structurally controlled nala sections with high runoff zones are higher susceptible zones for landslides. Apart from the above, field study reveals that the high angle slope modifications without retaining structures are much vulnerable to landslides.

\section{Acknowledgements:}

The author heartily thankful Dr. G S Srinivasa Reddy, Director, Karnataka State Natural Disaster Monitoring Centre (KSNDMC), Bengaluru for his encouragement during the study.

\section{References}

[1] Alimohammadlou. Y., Najafi, A., and Yalcin., A (2013). Landslide process and impacts: A proposed classification method. Catena, V.104: 219-232.

[2] Ankur Kumar Srivastava, Sunandan Basu, K V Maruthi, GSI (2018). A note on the preliminary post disaster investigation of Landslides occurred around madikeri, kodagu district, Karnataka

[3] Bommer, J.J., Rodriguez, C.E., (2002). Earthquake-induced landslides in Central America. Engineering Geology 63 (3-4), 189-220.

[4] Bishop, A.W. 1954. The Use of Pore-Pressure Coefficients in Practice. Geotechnique, Vol.4, No.4, pp.148-152.

[5] Bishop, A.W. 1955. The Use of the Slip Circle in the Stability Analysis of Slopes. Geotechnique (Proceedings of the Conference on the Stability of Earth Slopes, Stockholm, Sept. 20-25, 1954),Vol. 5, pp. 7-17.

[6] Brady NC, Weil RR (2007) The nature and properties of soils. Pearson Education, New Delhi, pp 756-761

[7] Campbell, R.H. 1975. Soil Slips, Debris Flows, and Rainstorms in the Santa Monica Mountains and Vicinity, Southern California. U.S. Geological Survey Professional Paper 851, 51 pp.

[8] Carrara, A. 1983. Multivariate Models for Landslide Hazard Evaluation. Mathematical Geology, Vol. 15, No. 3, pp. 403-427.

[9] Carrara, A. 1988. Landslide Hazard Mapping by Statistical Methods: A "Black Box" Approach. In Workshop on Natural Disasters in European Mediterranean Countries, Perugia, Italy, Consiglio Nazionale delle Ricerche, Perugia, pp. 205-224.

[10] Carrara, A., M. Cardinali, R. Detti, F. Guzzetti, V. Pasqui, and P. Reichenbach. 1990. Geographical Information Systems and Multivariate Models in Landslide Hazard Evaluation. In ALPS 90 Alpine Landslide Practical Seminar, Sixth International Conference and Field Workshop on Landslides, Aug. 31-Sept.12, Milan, Italy, Universitá degli Studide Milano, pp. 17-28.

[11] Carrara, A., M. Cardinali, R. Detti, F. Guzzetti, V. Pasqui, and P. Reichenbach. 1991. GIS Techniques and Statistical Models in Evaluating Landslide Hazard. Earth Surface Processes and Landforms, Vol. 16, No. 5, pp. 427-445.

[12] Carrara, A., M. Cardinali, and F Guzzetti. 1992. Uncertainty in Assessing Landslide Hazard and Risk. ITC Journal, No. 2, pp. 172183.

[13] Ellen, S.D., G.F. Wieczorek, W.M. Brown III, and D.G. Herd. 1988. Introduction. In Landslides, Floods, and Marine Effects of the Storm of January 3-5, 1982, in the San Francisco Bay Region, California(S.D. Ellen and G.F. Wieczorek, eds.), U.S.Geological Survey Professional Paper 1434, pp.1-5.

[14] Ellen, S.D, R.K. Mark, S.H. Cannon, and D.L. Knifong. 1993. Map of Debris-flow Hazard in the Honolulu District of Oahu, Hawaii. U.S. Geological Survey Open-File Report 93-2 13, 25 pp.

[15] Gryta, J.J., and M.J. Bartholomew. 1983. Debris-Avalanche Type Features in Watauga County, North Carolina. In Geologic Investigations in the Blue Ridge of Northwestern North Carolina (S.E.Lewis, ed.), Carolina Geological Society Guidebook, North Carolina Division of Land Resources, Boone, Article 5, 22 pp.

[16] Gryta, J.J., and M.J. Bartholomew. 1989. Factors Influencing the Distribution of Debris Avalanches Associated with the 1969 Hurricane Camille in Nelson County, Virginia. In Landslide Processes of the Eastern United States and Puerto Rico (A. P.Schultz and R.W. Jibson, eds.), Geological Society of America Special Paper 236, pp. 15-28. 
[17] Hartle'n, J., and L. Viberg, (1988). General report: Evaluation of landslide hazard, Proceedings of the 5th International Symposium on Landslides, Lausanne, 2:1037-1057.

[18] Isherwood, D., and Street, A., (1976), Biotite-induced grussification of the Boulder Creek Granodiorite, Boulder County, Colorado: Geol. Soc. America Bull., v. 87, p. 366-370

[19] Jacobson, R.B., E.D. Cron, and J.P. McGeehin. 1989. Slope Movements Triggered by Heavy Rainfall, November 3-5, 1985, in Virginia and West Virginia, U.S.A. In Landslide Processes of the Eastern United States and Puerto Rico (A.P. Schultz and R.W. Jibson, eds.), Geological Society of America Special Paper 236, pp. 1-14.

[20] Jibson, R.W. 1989. Debris Flows in Southern Puerto Rico. In Landslide Processes of the Eastern United

States and Puerto Rico (A.P. Schultz and R.W. Jibson, eds.), Geological Society of America Special Paper 236, pp. 29-56.

[21] Kochel, R.C. 1987. Holocene Debris Flows in Central Virginia. In Debris Flows/Avalanches: Process, Recognition, and Mitigation (J.E. Costa and G.F. Wieczorek, eds.), Reviews in Engineering Geology, Vol. 7, Geological Society of America, Boulder, Cob., pp. 139-155.

[22] Lambe, T.W., and R.V. Whitman. 1969. Soil Mechanics. John Wiley \& Sons, New York, 553 pp.

[23] Larsen, M.C., and A.J. Torres Sanchez. 1992. Landslides Triggered by Hurricane Hugo in Eastern Puerto Rico, September 1989. Caribbean Journal of Science, Vol. 28, No. 3-4, pp. 113-125.

[24] Mantovani, F., R. Soeters, and C.J. Van Westen, (1996). Remote sensing techniques for landslide studies and hazard zonation in Europe, Geomorphology, 15:213-225.

[25] Muralikrishnan S, Pillai A, Narender B, Shashivardhan Reddy V, Venkataraman Raghu, Dadhwal VK (2013) Validation of Indian National DEM from Cartosat-1 data. J Indian Soc Remote Sens 41(1):1-13

[26] Neary, D.G., and L.W. Swift, Jr. 1987. Rainfall Thresholds for Triggering a Debris Avalanching Event in the Southern Appalachian Mountains. In Debris Flows/Avalanches: Process, Recognition, and Mitigation (J.E. Costa and G.F. Wieczorek, eds.), Reviews in Engineering Geology, Vol. 7, Geological Society of America, Boulder, Cob.,pp. 8 1-92.

[27] Ozdemir H, Bird D (2009) Evaluation of morphometric parameters of drainage networks derived from topographic maps and DEM inpoint of floods. Environ Geol 56:1405-1415

[28] Pravat Kumar Shit, Gouri Sankar Bhunia, Ramkrishna Maiti. (2016). Potential landslide susceptibility mapping using weighted overlay model (WOM). Model. Earth Syst. Environ. 2:21.

[29] Raghuvanshi, T.K., Ibrahim, J., Ayalew, D., (2014). Slope stability susceptibility evaluation parameter (SSEP) rating scheme - an approach for landslide hazard zonation. J. Afr. Earth Sci. 99, 595-612.

[30] Simon, A., M.C. Larsen, and C.R. Hupp. 1990. The Role of Soil Processes in Determining Mechanisms of Slope Failure and Hillside Development in a Humid-Tropical Forest, Eastern Puerto Rico. Geomorphology, Vol. 3, pp. 263-286.

[31] Strahler AN (1964), Quantitative geomorphology of drainage basinsand channel networks. In: Chow VT (ed) Handbook of appliedhydrology. McGraw-Hill, New York, pp 439-476

[32] Terzaghi, K. 1943. Theoretical Soil Mechanics. John Wiley and Sons, Inc., New York, 510 pp.

[33] Varnes, D.J., (1978). Slope movement: types and processes. In: Schuster, R.L., Krizek, R.J. (Eds.), Landslides: Analysis and Control. Transportation Research Board, Special Report, 176. National Research Council, Washington, DC, pp. 11-33.

[34] Varnes, D.J. (1984) Landslide Hazard Zonation: A Review of Principles and Practice, Natural Hazards. UNESCO, Paris

[35] Wahrhaftig, C., 1965, Stepped topography of the southern Sierra Nevada, California: Geol. Soc. America Bull., v. 76, p. 1165-1190.

[36] Wilson, R.C., J.D. Torikai, and S.D. Ellen. 1992. Development of Rainfall Warning Thresholds for Debris Flows in the Honolulu District, Oahu. U.S. Geological Survey Open-File Report 92-521, 45 pp. 